\title{
Optimization of 'On Farm' Hydropriming Conditions In Wheat: Soaking Time And Water Volume Have Interactive Effects On Seed Performance
}

Hemender Tanwar ( $\nabla$ hemender.sst@gmail.com )

Chaudhary Charan Singh Haryana Agricultural University

Virender Singh Mor

Chaudhary Charan Singh Haryana Agricultural University

Sushma Sharma

Chaudhary Charan Singh Haryana Agricultural University

Mujahid Khan

Sri Karan Narendra Agriculture University, Jobner

\section{Axay Bhuker}

Chaudhary Charan Singh Haryana Agricultural University

Vikram Singh

Chaudhary Charan Singh Haryana Agricultural University

Jitender Yadav

Chaudhary Charan Singh Haryana Agricultural University

\section{Sonali Sangwan}

Chaudhary Charan Singh Haryana Agricultural University

Jogender Singh

Chaudhary Charan Singh Haryana Agricultural University

Shikha Yashveer

Chaudhary Charan Singh Haryana Agricultural University

Kuldeep Singh

Chaudhary Charan Singh Haryana Agricultural University

\section{Research Article}

Keywords: Hydropriming, Imbibition, Soaking duration, Water volume, Germination

Posted Date: December 14th, 2021

DOI: https://doi.org/10.21203/rs.3.rs-1097189/v1 
License: (c) (i) This work is licensed under a Creative Commons Attribution 4.0 International License. Read Full License 


\title{
Optimization of 'on farm' hydropriming conditions in wheat: Soaking time and water volume have interactive effects on seed performance
}

\author{
Hemender Tanwar*1+, Virender Singh Mor ${ }^{1+}$, Sushma Sharma ${ }^{1+}$, Mujahid Khan ${ }^{2+}$, Axay \\ Bhuker1, Vikram Singh ${ }^{3}$, Jitender Yadav ${ }^{1}$, Sonali Sangwan ${ }^{4}$, Jogender Singh ${ }^{5}$, Shikha \\ Yashveer $^{4}$ and Kuldeep Singh ${ }^{5}$ \\ ${ }^{1}$ Department of Seed Science and Technology, Chaudhary Charan Singh Haryana Agricultural University, \\ Hisar, India-125004 \\ ${ }^{2}$ Agricultural Research Station (S.K.N. Agriculture University, Jobner), Fatehpur Shekhawati, Sikar, \\ Rajasthan, India -332301 \\ ${ }^{3}$ Department of Genetics and Plant Breeding, Chaudhary Charan Singh Haryana Agricultural University, \\ Hisar, India-125004 \\ ${ }^{4}$ Department of Molecular Biology, Biotechnology and Bioinformatics, Chaudhary Charan Singh Haryana \\ Agricultural University, Hisar, India-125004 \\ ${ }^{5}$ Krishi Vigyan Kendra, Sonepat, Chaudhary Charan Singh Haryana Agricultural University, Hisar, India- \\ 125004 \\ *corresponding author email: hemender.sst@gmail.com \\ +these authors contributed equally to this work
}

\section{ABSTRACT}

Seed priming is a simple and cost effective method to obtain a better plant stand under diverse environmental conditions. The current study was designed to determine the optimal priming duration and water volume for wheat seed. For this experiment, three wheat genotypes with distinct genetic and adaptive backgrounds were chosen. Seeds of each genotype were hydroprimed for 7 durations, i.e. 1, 2, 4, $8,12,16$, and 20 hours, in three different water volumes, i.e. half, equal, and double volume with respect to seed weight. The control was unprimed (dry) seed. The germination characteristics and seedling vigour potential of hydroprimed seeds were evaluated in the lab by recording several parameters such as germination percentage and speed, seedling growth, and vigour indices at two different temperature levels. The results showed that optimal duration for hydropriming of wheat seed is 12 hours with an equal volume with respect to original seed weight, closely followed by 8 hours with double volume. Reduction in seed performance was observed at 16 and 20 hours priming particularly at double volume treatment. Effect of temperature on seed germination showed improvement in seedling vigour at $25^{\circ} \mathrm{C}$ when compared to $20^{\circ} \mathrm{C}$, although germination percentage decreased slightly. Volume of water and priming duration showed significant interactive effects demonstrating that a higher volume can give equivalent results at a shorter duration and vice versa.

Keywords: Hydropriming, Imbibition, Soaking duration, Water volume, Germination

\section{Introduction}

Enhancement of seed performance by conditioning them in simple water (seed hydropriming) has been known for many years ${ }^{1}$. Seed priming accelerates pre-germination metabolism, resulting in faster seedling emergence and a more uniform plant stand in the field ${ }^{2,3}$. Primed seeds quickly absorb water, accompanied by ion and solute leakage, which stimulates repair of structural and oxidative damage caused by desiccation, and membrane integrity is restored, resulting in rejuvenation of respiration and 
metabolism ${ }^{4}$. Seeds that have been well-primed germinate faster and more evenly than unprimed seeds, and priming also confers stress tolerance at an early stage of plant growth.

Hydropriming is the most basic, cost-effective, and ecologically safe technique for improving seed performance in the field, enhancing plant stand, and crop output under both stressed and normal conditions ${ }^{5}$. It is the most basic method of seed priming, involving seed soaking in pure water followed by re-drying to the initial moisture level before to sowing. Changes caused by hydopriming can be classified into three distinct phases ${ }^{6}$. Due to the water potential difference in the system, the seed absorbs water quickly in Phase I (seed having lower water potential). The key events occurring during this phase include DNA and mitochondrial repairs, as well as the synthesis of new protein molecules from ex isting mRNA. In phase II, seed metabolism gets activated, mitochondrial synthesis begins, and protein synthesis is accelerated via translation of newly generated mRNAs. Phase III is characterized by rapid cell division and elongation, which aids in tissue growth and leads to germination, i.e. radicle protrusion. However, priming only allows seed hydration throughout phase I and before the completion of phase II, where germination remains a reversible process and stops just short of radicle protrusion ${ }^{7}$.

On-farm priming is a type of hydropriming that involves soaking seed in water, drying briefly, and then sowing. The period of treatment must not exceed the "safe limit" (the maximum time of priming without risk of seed or seedling damage due to premature germination $)^{8}$. The positive impact of this method on crop emergence and yield was confirmed by Harris et al. ${ }^{9}$. On-farm priming is particularly beneficial for resource-constrained farmers in marginal tropical environments ${ }^{10}$. However, a drawback of this procedure is that seeds would absorb water in unregulated manners as farmers use non-standardized method (generally soaking the seed overnight). As a result, seeds have unrestricted access to water, and the tissue affinity of the seed to water is the only factor determining the rate of seed water intake ${ }^{11}$. This approach may cause non-uniform seed hydration, resulting in unsynchronized metabolic activation in seeds and non-homogeneous emergence ${ }^{12}$. If the seed's water absorption during hydropriming is not carefully maintained to a safe limit, it can injure the seed and cause it to lose vigour. Furthermore, the water absorption capacity and response to hydropriming of different crop species/genotypes vary in nature. These constraints emphasize the significance of standardizing the specific conditions of this procedure, such as treatment duration, temperature, and water volume, in order to achieve the optimal seed hydration. Therefore, the current study was aimed to determine the ideal soaking duration and water volume for hydropriming of wheat seed.

\section{Results}

Imbibition pattern

Water imbibition at different water volumes of soaking and duration demonstrated that half volume with respect to seed weight is insufficient to achieve maximum absorption. While imbibition in seeds soaked in equal and double volumes resulted in the same amount of water absorbed, the rate of absorption differed under each volume treatment. The difference between these two volume treatments was significant up to 8 hours of soaking duration, but it became inconsequential at 12,16, and 20 hours. Typically, the wheat seed absorbed roughly 50 percent water with regard to its weight upto 8 hours of soaking and the general peak in water absorption was noted at 16 hours, following which there was a very small augmentation at 20 hours.

Moisture content following hydropriming also exhibited a similar pattern (Fig. 1). The moisture content of dry seed (control) was approximately 10\%. Moisture content increased sharply during the first hour of priming in all three volume treatments. Their magnitudes of increase, however, were different, and half volume treatment resulted in a lower increase. Moisture content increased to a maximum of 16 hours after priming and then stabilized. Moisture was somewhat comparable between equal and double volume treatments with double volume having a slightly higher value and peaking at around $40 \%$ at 16 
hours. Whereas, half volume demonstrated significantly lower moisture contents across all durations, reaching a maximum of $35 \%$.

\section{Germinating characteristics}

Germination tests were performed on each cultivar to determine the most promising duration of soaking at various volume levels. Germination percentage was significantly influenced by varied soaking times $(\mathrm{p}<0.01)$ (Table 2$)$, and it gradually rose with time up to 12 hours at both temperatures. However, the values were statistically equivalent to those obtained after 8 hours (at $25^{\circ} \mathrm{C}$ ) and 4 hours $\left(\right.$ at $20^{\circ} \mathrm{C}$ ). Germination decreased at the duration more than 12 hours, with the lowest recorded at 20 hours (even lower than unprimed dry seed). In terms of germination speed, the impacts were comparable, with seeds primed for 12 hours germinating faster. Although the speed was slower at 16 and 20 hours, the seeds germinated faster than unprimed seeds.

Different water volume treatments had no effect on final germination percentage $(\mathrm{p}=0.82)$ (Table

2 ). However, their influence was significant in terms of germination speed $(p<0.01)$, with equal volume of water being the fastest followed by double volume treatment, and seeds primed with half volume germinating at a slower rate. For both these traits, the interactive effect of volume and duration was also prominent (Fig. 2). The highest number of seeds germinated after 12 hours of hydropriming with half volume of water, followed by 12 hours of equal volume and 8 hours of double volume, all with the same germination percentage. When primed in equal and half amounts of water, the seeds germinated faster at 12 hours, however at double volume, 8 hours was shown to be the optimum.

Genotypic differences were also found to be significant $(\mathrm{p}<0.01)$ (Table 2), with WH 1105 outperforming WH 1124 and KRL 213 in terms of final germination percentage. However, WH 1124 outperformed the other two genotypes in terms of germination speed. The genotype KRL 213 performed poorly in terms of germination percentage and speed.

\section{Seedling growth and biomass}

On the day of the final count of standard germination test, seedling growth metrics such as shoot, root, and seedling length were recorded. The volume treatments had a significant $(\mathrm{p}<0.01)$ effect on shoot length at both temperatures, but they have a significant $(\mathrm{p}<0.01)$ effect on root and seedling length only at $25^{\circ} \mathrm{C}$ (Table 3 ). Half and equal volume effects were statistically similar and higher than double volume, indicating that soaking in half and equal volume is better for seedling growth than soaking in double volume. The genotypic variations influenced seedling growth metrics significantly $(\mathrm{p}<0.01)$. At both temperatures, shoots were longer in genotypes WH 1105 and KRL 213 than in WH 1124. On the other hand, WH 1124 generated longer roots than the other two genotypes (Table 3). Seedling length did not differ significantly $(\mathrm{p}>0.01)$ among the three genotypes at $20^{\circ} \mathrm{C}$, but it did differ considerably $(\mathrm{p}<0.01)$ at $25^{\circ} \mathrm{C}$ (Table 3). When compared to WH 1124, the genotypes KRL 213 and WH 1105 showed statistically similar and longer seedling length. The genotype WH 1105 had the longest roots and seedlings at $20^{\circ} \mathrm{C}$, ranking first among the three genotypes, while it ranked worst at $25^{\circ} \mathrm{C}$, showing its sensitivity to temperature change. In terms of priming duration, the maximum value of shoot, root, and seedling length was reported after 12 hours of hydropriming, followed by 8 hours. At both temperature conditions, the interactive effect of duration and amount of water was significant $(\mathrm{p}<0.01)$. The interaction effect of volume and duration revealed that seedling development was greatest at 12 hours with half volume treatment, closely followed by similar duration with equal volume at $20^{\circ} \mathrm{C}$ temperature (Fig. 3). At $25^{\circ} \mathrm{C}$, the treatment 12 hours with equal volume was determined to be the best, while the priming for 12 hours with half volume was shown to be the second best (Fig. 3). All priming treatments significantly increased shoot length compared to the control (unprimed seed) at both temperature levels, but 20 hours duration exhibited a lower value than the control at $25^{\circ} \mathrm{C}$. 
The amount of biomass accumulated in seedlings was calculated by recording their fresh and dried weight at 8 DAS (days after sowing). At both temperature levels, water volume had no significant effect on seedling biomass. However, the genotypic effect was significant, with the genotype WH 1124 having the highest seedling fresh and dry weight at both temperatures (Table 4). The genotype WH 1105 scored second at $20^{\circ} \mathrm{C}$, but at $25^{\circ} \mathrm{C}$, it demonstrated its sensitivity to high temperature by ranking last in terms of seedling fresh and dry weight (Table 4). In terms of trait specific trend, the quantity of variation between genotypes was greater in the case of fresh weight than dry weight. Maximum seedling fresh and dry weight were reported at 12 hours of hydropriming, which was statistically equivalent to 8 hours at both temperatures. Hydropriming for more than 12 hours, on the other hand, indicated a diminishing tendency. However, at $20^{\circ} \mathrm{C}$ and $25^{\circ} \mathrm{C}$, the lowest value of seedling fresh weight was reported in unprimed (dry) seed. At $25^{\circ} \mathrm{C}$, a substantial relationship between volume and duration was also discovered. This interaction revealed that the highest values of seedling fresh and dry weight for half volume and equal volume were observed at 12 hours, whereas hydropriming with double volume produced the highest biomass at 8 hours (Fig. 4).

\section{Seedling vigour indices}

The effect of different volume treatments on the vigour index-I was found to be significant at $25^{\circ} \mathrm{C}$ but not at $20^{\circ} \mathrm{C}$. The highest vigour index-I was obtained after hydropriming with half the volume of water, which was statistically equivalent to equal volume followed by double volume (Table 5). In the case of vigour index-II, however, the effect was non-significant. Among the genotypes, the genotype WH 1124 had the highest vigour index-I value, whereas the genotypes WH 1105 and KRL 213 were recorded with lower values but statistically at par with each other at $20^{\circ} \mathrm{C}$ (Table 5). The vigour index-II showed a similar pattern, with the highest value in WH 1124, followed by WH 1105 and KRL 213. At $25^{\circ} \mathrm{C}, \mathrm{WH}$ 1124 was shown to be superior, but the performance of WH 1105 was diminished, with lower values for both vigour indices when compared to KRL 213 (Table 5). In terms of priming duration, 12 hours was determined to be the most effective, followed by 8 hours at $20^{\circ} \mathrm{C}$. However, at $25^{\circ} \mathrm{C}$, the highest vigour was obtained after 12 hours of hydropriming, which was statistically equal to the values found at 8 hours treatment (Table 5). Under both temperature levels, the 20-hour period yielded the lowest values of vigour indices, which were considerably lower than the control (unprimed seed). The interaction effect of volume and duration showed that seeds primed for 12 hours had the highest vigour followed by 12 hours priming with half volume of water at both temperatures (Fig. 5).

\section{Hydropriming Optimization Score (HPOS)}

The evaluation of multiple treatment combinations based on HPOS indicated that all priming treatments were superior than the unprimed control (Table 6). The ranking based on the score was not consistent with the corresponding treatment's germination percentage or germination speed. Rankings, on the other hand, confirmed the interaction effect of soaking duration and water volume used during priming. The top three treatments were 12 hours with equal volume, 8 hours with double volume, and 12 hours with half volume. Similarly, control (dry seed), 20 hours with same volume and 1 hour with half volume, occupied the last three ranks, respectively (Table 6).

\section{Correlation analysis}

Water exposure index (WEI) and seed moisture content were also correlated with germination and seedling vigour indices. WEI and seed moisture both had a negative relationship with germination percentage and seedling vigour, according to the correlation analysis. WEI showed a strong $(\mathrm{p}<0.01)$ negative correlation ( $\mathrm{r}=-600$ ) with standard germination (Table 7.). In the case of seedling vigour indices, the association was also negative ( $\mathrm{r}=-0.465$ and -0.519 for vigour index-I and II, respectively), but with normal significance $(\mathrm{p}<0.05)$ (Table 7.). The relationship between WEI and germination speed, on the other hand, was not statistically significant $(\mathrm{p}>0.05)$, but it was positive in nature $(\mathrm{r}=0.053)$. 
Moisture content of seed had a negative relationship with germination percentage $(r=-0.317)$ and vigour indices ( $\mathrm{r}=-0.120$ and -0.156 for vigour index-I and II, respectively), but this was not statistically significant $(\mathrm{p}>0.05)$. However, the moisture content of the seed had a positive significant $(\mathrm{p}<0.05)$ relationship $(r=-0.441)$ with the speed of germination.

\section{Discussion}

Seed priming can help improve seedling emergence and establishment in the field. In a hostile field environment, seed hydropriming's benefits would be highly valuable. Practical aspects are vital because they represent actual application on the farmer's field. The present study attempted to work out optimal duration and water volume for hydropriming by assessing several parameters like water absorption, seed moisture, germination and seedling vigour of three prominent wheat genotypes. The pattern of water absorption under different specifications of hydropriming showed that water is absorbed rapidly at shorter durations and rose dramatically up to 16 hours, after which it decreased significantly. Comparable results were reported in a previous study, with maximum water absorption at 16 hours of soaking in wheat seed ${ }^{13}$. Under all three volume treatments, about half of the water was absorbed within 8 hours. This is a feature of the phase I 'imbibition' stage and shows the fast hydration of interior seed tissues ${ }^{14}$. As imbibition is essentially a passive process that serves as a catalyst for the resumption of metabolic activity, the priming period must be long enough to ensure that germination processes are sufficiently advanced to allow for pre-germinative effects to take place. However, the timing of these events varies based on cultivar, seed quality, and priming specifications.

The hydropriming up to 12 hours enhanced the germination percentage and other seed vigour metrics when compared to the control. Durations greater than 12 hours, i.e. 16 and 20 hours, resulted in a considerable drop in germination and other seed vigour parameters, particularly at the double volume. Hydropriming of wheat for more than 12 hours has previously been reported to be damaging to seed ${ }^{15}$. The standard germination percentage was found to be highest at 12 hours soaking with half and equal volumes at both $20^{\circ} \mathrm{C}$ and $25^{\circ} \mathrm{C}$, however when seeds were primed in double volume, the highest germination was obtained at 8 hours. These findings are similar to some previous reports which suggested that 12 hours hydropriming is best for wheat seed ${ }^{15,16}$. The increased germination of primed seeds could be attributable to readily available nourishment to primed seeds, allowing them to finish the germination process considerably faster than dry seeds ${ }^{17,18}$. Seed priming also repairs metabolic damage to the genomic DNA caused by desiccation of seeds, enhances mitochondrial membrane quality, seed energy, and ATP/ADP ratio which in turn improves its performance over unprimed seeds ${ }^{19}$. However, there are some studies in the literature which recorded maximal germination potential in wheat after 16 and 18 hours priming ${ }^{13,20}$.

Genotypic differences revealed that the genotype WH 1124 had maximum germination potential and other seed vigour parameters at both the temperatrure levels. It was followed by WH 1105, and finally by KRL 213. Genotypic variations are common in germination and seedling vigour related traits ${ }^{21}$. The larger seed size of genotype WH 1124 may explain its higher germination and vigour potential when compared to the other two genotypes. The results also revealed that WH 1124 and KRL 213 performed better at higher temperatures i.e. $25^{\circ} \mathrm{C}$. These two genotypes were developed specifically for stressed conditions. KRL 213 is a salt tolerant genotype, and WH 1124 is recommended for late sowing. Their better performance at higher temperature suggests that the characteristics that makes a genotype tolerant to one type of abiotic stress can help it perform better under other types of abiotic stresses as well. WH 1105 , on the other hand, which is recommended for planting under normal conditions, demonstrated heat stress sensitivity at the germination stage even after priming. 
Among the three volume treatments, half and equal volumes demonstrated higher germination and vigour than double volume, where most of the parameters declined. This could be due to a lack of appropriate aeration and development of anaerobic conditions in the seeds dipped in double volume. The rate of water absorption rises as anaerobic conditions develop, potentially causing seed damage ${ }^{22}$. For example, hydropriming with water in the range of 90-100 percent of seed weight was shown to be optimum in lucerne seeds and higher amount of water resulted in reduction of seed performance ${ }^{23}$. While, in case of cowpea seeds, a volume twice the seed weight produced better results than a half and equal volume, however, the priming duration was shorter ( 2 hours $)^{24}$. These findings suggest that water absorption varies by crop species and should be standardized under diverse set of priming conditions.

The decline of seed performance after a specific priming duration could be attributed to seed degradation caused by unregulated water absorption. Seed/seedling performance reductions in vigour tests at and after a particular timing are unambiguous indications of extremely lengthy priming duration ('overpriming'). Another factor may be the accumulation of fermentation products in excess as a result of the extended hypoxic conditions during 'on-farm' seed priming conditions, responsible for a gradual loss of vigour $^{25}$. The duration which produces best outcomes of seed priming differs in different crop species/seed type. For example, 18 hours was found optimum for maize ${ }^{20}$, for rice 48 hours was found optimum $^{26}$, in lucerne it was 3-5 days ${ }^{23}$ and for cowpea, only 2 hours priming was found enough ${ }^{24}$.

The study established the interaction effects of volume and length of soaking duration, implying that the extent of water exposure plays a key role in outcomes of hydropriming. Using an ideal water exposure environment throughout the priming process, the germination potential in terms of speed and overall percentage, as well as the growth of subsequent seedlings, can be optimized. The outcomes of 'onfarm' seed priming under varied climatic conditions are mostly influenced by two major criteria for quick germination: (1) the level of hydration of the seed; (2) the advantages of developmental advancement over dry seeds at the time of sowing. Rapid hydration of interior tissues is the primary cause of faster germination in primed seeds ${ }^{14}$. In the present study, the first 4 hours of soaking resulted in a significant improvement in germination speed compared to dry seed (64 percent out of total 84 percent improvement at $20^{\circ} \mathrm{C} ; 51$ percent out of total 69 percent improvement at $25^{\circ} \mathrm{C}$ ). These findings are consistent with a study in which length of on-farm priming was standardized in barley seeds ${ }^{14}$. In this study, it was determined that the rapid boost in germination speed after a few hours of priming is mostly related to the first rapid hydration of seed tissues, whereas developmental advancement is the primary source of improvements at longer soaking times.

Under varying environmental conditions, seedling vigour is the most significant seed quality attribute because it is critical in the establishment of freshly emerged seedlings under hostile field environment ${ }^{27}$. Priming has a significant positive impact on seedling vitality. However, it is highly dependent on the precision and specificity of ideal priming techniques. The highest gain in vigour can be obtained by stopping priming right before the start of phase III. The completion of numerous pregerminative phenomena, including protein synthesis, mitochondrial synthesis, and other cellular repair mechanisms, is critical in increasing vigour during this stage. However, if the seed enters phase III during the priming process, it will begin cell division and elongation, resulting in radicle protrusion and a loss of vigour obtained by priming ${ }^{28,29,30}$. Therefore, the optimal priming length should correspond to a stage of maximum molecular production and cellular repair ${ }^{29,31,32}$.

\section{Significance at farmers' field}

In agriculture, the true worth of a technique is found in its applicability on the farmer's field. Farmers have known about seed priming for a long time and practice it as per their convenience. They typically soak the seed overnight without taking into account important aspects influencing the process. The findings of present study may be useful in terms of adjusting length and volume based on the actual farm conditions. The current study demonstrates that 12 hours of hydropriming with an equal volume of 
water to the seed weight works best for wheat seeds. If the farmer is in a rush to sow, he/she can opt for 8 hours of hydropriming with double volume of water rather than 12 hours of priming with half or equal volume. Moreover, these optimal conditions showed similar trend in all the three varieties studied, therefore can be used for other wheat seeds in general.

\section{Methods}

Seed material and priming treatments

The seed of three Indian bread wheat genotypes (WH 1105, WH 1124 and KRL 213) was

obtained from Wheat and Barley Section, Department of Genetics and Plant Breeding, Chaudhary Charan Singh Haryana Agricultural University, Hisar. The genotypes were selected based on their diverse genetic backgrounds and adaptation to different growing environments (Table 1). They represent a standard sample from seed supply chain of wheat in the area. Seeds were stored under ambient conditions prior to the experiment.

Table 1. Details of genotypes used in the study

\begin{tabular}{llll}
\hline $\begin{array}{l}\text { Sr. } \\
\text { No. }\end{array}$ & $\begin{array}{l}\text { Name of the } \\
\text { genotype }\end{array}$ & Year of release & Recommended for \\
\hline 1. & WH 1105 & 2013 & Normal sown \\
2. & WH 1124 & 2014 & Late sown \\
3. & KRL 213 & 2010 & Salt tolerant \\
\hline
\end{tabular}

The priming treatments were applied in all combinations and seeds were soaked in tap water in $100 \mathrm{ml}$ glass beakers, at $25^{\circ} \mathrm{C}$ in the dark. After treatment, seeds were allowed to air-dry on a paper towel for an hour (to avoid clumping). In all cases, non-primed dry seed was used as control. Twenty gram seed from each genotype was soaked in 10 (Half volume (w/v), 20 (Equal volume (w/v) and $40 \mathrm{ml}$ (Double volume (w/v) water for either 1, 2, 4, 8, 12,16, or $20 \mathrm{~h}$ in triplicate for each soaking time. Three samples of unsoaked seeds (10 g each) were oven-dried at $103^{\circ} \mathrm{C}$ for $17 \mathrm{~h}$ to determine initial moisture content $(\mathrm{Mc})^{33}$. The soaked samples were also weighed before and after soaking for determination of their final moisture content $(\mathrm{Mc})$ after priming, which was calculated as follows:

$$
M c=\left(\frac{M_{2}-M_{3}}{M_{2}-M_{1}}\right) \times 100
$$

Where, $\mathrm{M}_{1}$ is weight of empty container, $\mathrm{M}_{2}$ is weight of container with seed before drying and $\mathrm{M}_{3}$ is weight of container with seed after drying.

Water Exposure Index (WEI) during different combinations of hydropriming conditions was calculated by using following formula:

$$
W E I=\sqrt{w v} \times s d
$$

Where, $w v$ is water volume denoting fixed values either 0.5 (half volume), 1 (equal volume) or 2 (double volume) and $s d$ is the soaking time in minutes.

Experimentation

Standard germination percentage and seedling related traits were recorded by using 'Between Paper' method ${ }^{33}$ for germination testing. One hundred healthy unbroken seeds of each genotype were taken and placed equidistantly between two sufficiently moistened towel papers. These towel papers were then rolled and covered with a layer of wax paper to avoid the moisture loss and kept on steel racks in growth chambers maintained at $20^{\circ} \mathrm{C}$ and $25^{\circ} \mathrm{C}$ in dark conditions for 8 days.

For assessing the speed of germination, 'Top of the Paper' method was used. Fifty seeds were planted on moistened filter paper kept in plastic petri plates. These petri plates were then kept in the 
germinators under the same experimental conditions for 8 days. The relative humidity during the course of experiments was maintained at $90 \pm 2 \%$. The experiments were laid out in a completely randomized design in a factorial arrangement and replicated thrice.

Observations recorded

The final count of germination was taken on $8^{\text {th }}$ day and normal seedlings were considered for percent germination ${ }^{33}$ and values were expressed in percentage. The newly emerged radicals of germinated seeds were counted on a daily basis. Speed of germination was calculated based on the following formula ${ }^{34}$ :

Speed of germination $=\frac{\mathrm{X} 1}{\mathrm{Y} 1}+\frac{\mathrm{X} 2-\mathrm{X} 1}{\mathrm{Y} 2}+\cdots+\frac{\mathrm{Xn}-\mathrm{Xn}-1}{\mathrm{Yn}}$

Where,

$X_{1}, X_{2}$ and $X_{n}=$ number of seeds germinated on the first, second and $n^{\text {th }}$ day, respectively

$\mathrm{Y}_{1}, \mathrm{Y}_{2}$ and $\mathrm{Y}_{\mathrm{n}}=$ number of days from sowing to first, second and $\mathrm{n}^{\text {th }}$ count, respectively

Thirty seedlings were randomly selected from the 'Between Paper' samples and their shoot and root lengths were measured at 8 DAS. Average of the 30 seedlings was taken for the final calculation. Fresh weight of seedlings from each replicate was also recorded immediately. For the estimation of dry weight, the seedlings whose fresh weight was recorded were dried in a hot air oven for 24 hours at $80 \pm 1^{\circ} \mathrm{C}$. The dried seedlings of each replication were weighed and dry weight of single seedling was calculated by taking the average for each and expressed in milligrams. The seedling vigour index-I and vigour index-II were calculated by the formulae suggested by Abdul-Baki and Anderson ${ }^{35}$ and expressed as a whole number.

Seedling Vigour Index-I = Standard germination $(\%) \times$ Average seedling length $(\mathrm{cm})$

Seedling Vigour Index-II = Standard germination $(\%) \times$ Average seedling dry weight $(\mathrm{mg})$

Hydropriming Optimization Score (HPOS) was determined using Standard Germination (SG) and Germination Speed (GS), using the following formula:

$$
H P O S=\frac{2 \times S G \times G S}{S G+G S}
$$

This formula was developed by modifying the basic formula described in a previous study ${ }^{23}$. Statistical Analysis

The data from different treatment combinations are presented as the mean value with standard error (error bars) of three replicates in the tables or graphical form. All the data were analyzed in Completely Randomized Design (CRD) using STAR 5.1: Statistical Tool for Agricultural Research of International Rice Research Institute (IRRI). Percentage data of standard germination were arc-sine transformed. Three -way ANOVA was used to detect the effect of genotype, water volume and soaking duration on different seed germination and seedling vigour parameters. Least significant difference (LSD) test was used at 0.05 probability levels to check the difference between different treatments.

\section{References}

1. Lang, A. Effects of some internal and external conditions on seed dormancy. In: W. Ruhland, ed. Encyclopedia of Plant Physiology. Springer-Verlag, Berlin. Vol. 15. pp. 848-893, (1965).

2. Bradford, K. J. Water Relations in Seed Germination. In: Kigel, J. and Galili, G, Eds., Seed Development and Germination, Marcel Dekker, Inc, New York. pp. 351-396, (1995).

3. Jisha, K. C., Vijayakumari, K. \& Puthur, J. T. Seed priming for abiotic stress tolerance: an overview. Acta Physiol. Plant. 35,1381-1396, DOI: https://doi.org/10.1007/s11738-012-1186-5, (2013). 
4. Kranner, I., Minibayeva, F. V., Beckett, R. P. \& Seal, C. E. What is stress? Concepts, definitions and applications in seed science. New Phytol. 188,655-673, DOI: https://doi.org/10.1111/j.14698137.2010.03461.x, (2010).

5. Kaur, S., Gupta, A. K. \& Kaur, N. Effect of osmo- and hydropriming of chickpea seeds on seedling growth and carbohydrate metabolism under water deficit stress. Plant Growth Regul. 37(1),17-22, DOI: https://doi.org/10.1023/A:1020310008830, (2002).

6. Bewley, J. D. Seed germination and dormancy. Plant Cell 9(7),1055-1066, DOI: https://dx.doi.org/10.1105/tpc.9.7.1055, (1997).

7. Bray, C. M. Biochemical processes during the osmopriming of seeds. In: Kigel J, Galili G (eds) Seed development and germination. Marcel Dekker, New York, pp 767-789, (1995).

8. Harris, D., Joshi, A., Khan, P. A., Gothkar, P. \& Sodhi, P. S. On-farm seed priming in semi-arid agriculture: development and evaluation in maize, rice and chickpea in India using participatory methods. Exp. Agric. 35,15-29, DOI: https://doi.org/10.1017/S0014479799001027, (1999).

9. Harris, D., Raghuwanshi, B. S., Gangwar, J. S., Singh, S. C., Joshi, K. D., Rashid, I. \& Hollington, P. I. Participatory evaluation by farmers for on-farm seed priming in wheat in India, Nepal and Pakistan. Exp. Agric. 37,403-415, DOI: https://doi.org/10.1017/S0014479701003106, (2001).

10. Harris, D., Breese, W. A. \& Kumar Rao, J. V. D. K. The improvement of crop yield in marginal environments using 'on-farm' seed priming: nodulation, nitrogen fixation and disease resistance. Aust. J. Agric. Res. 56,1211-1218, DOI: http://doi.org/10.1071/AR05079, (2005).

11. Taylor, A. G., Allen, P. S., Bonnett, M. A., Bradford, K. J., Burris, J. S. \& Misra, M. K. Seed enhancements. Seed Sci. Res. 8(2),245-256, DOI: http://doi.org/10.1017/S0960258500004141, (1998).

12. McDonald, M. B. Seed priming. In: Black, M., Bewley, J.D. (Eds.), Seed Technology and Its Biological Basis. Sheffield Academic Press, Sheffield, England, pp. 287-325, (2000).

13. Patra, S. S., Mehera, B., Rout, S., Tomar, S. S., Singh, M. \& Kumar, R. Effect of hydropriming and different sowing dates on growth and yield attributes of Wheat (Triticum aestivum L.). J. Appl. Nat. Sci. 8(2),971-980 (2016).

14. Carrillo-Reche, J., Newton, A. C. \& Quilliam, R. S. Using seed respiration as a tool for calculating optimal soaking times for 'on-farm' seed priming of barley (Hordeum vulgare). Seed Sci. Res. 1-9, DOI: http://doi.org/10.1017/S0960258521000039, (2021).

15. Giri, G. S. \& Schillinger, W. F. Seed priming winter wheat for germination, emergence and yield. Crop Sci. 43,2135-2141, DOI: http://doi.org/10.2135/cropsci2003.2135, (2003).

16. Yari, L., Aghaalikani, M. \& Khazaei, M. Effect of Seed Priming Duration and Temperature on Seed Germination Behavior of Bread Wheat (Triticum aestivum L.). ARPN J. Agric. Biol. Sci. 5(1),1-6, (2010).

17. Kant, S., Pahuja, S. S. \& Pannu, R. K. Effect of seed priming on growth and phenology of wheat under late sown conditions. Trop. Sci. 44,9-15, DOI: https://doi.org/10.1002/ts.123, (2006).

18. Farooq, M., Barsa, S. M. A. \& Khan, M. B. Seed priming improves growth of nursery seedlings and yield of transplanted rice. Arch. Agron. Soil Sci. 53,315-326, DOI: http://doi.org/10.1080/03650340701226166, (2007).

19. Varier, A., Kuriakose, A. \& Dadlani, M. The subcellular basis of seed priming. Curr. Sci. 99(4),450456, (2010).

20. Mahmoodi, T. M., Ghassemi-Golezani, K., Habibi, D., Paknezhad, F. \& Ardekani, M. R. Effect of hydro-priming duration on seedling vigour and field establishment of maize (Zea mays L.). Res. on Crops. 12(2),341-345, (2011).

21. Sharma, S., Yashveer, S., Singh, V., Punia, R. C., Hemender, Sangwan, S., Mor, V. S. \& Khan, M. Systematic trait based identification and characterization of Indian wheat varieties released during 
different time scales. J. Environ. Biol. 41,1748-1760, DOI: http://doi.org/10.22438/jeb/41/6/SI-272, (2020).

22. Rahman, M. M., Ahammad, K. U. \& Alam, M. M. Effect of Soaking Condition and Temperature on Imbibition Rate of Maize and Chickpea Seeds. Res. J. Seed Sci. 4,117-124, (2011).

23. Liu, H. X., Guo, Z. G. \& Wang, Y. R. Optimal conditions for hydropriming lucerne seeds. New Zealand J. Agric. Res. 51,69-75, (2008).

24. Mor, V. S., Bhuker, A., Dahiya, O. S. \& Sangwan, V. P. Seed Hydropriming a nice tool for enhancement of viability and vigour in cowpea. Forage Res. 40(2),77-79, (2014).

25. Benvenuti, S. \& Macchia, M. Effect of hypoxia on buried weed seed germination. Weed Res. 35,343-351, DOI: https://doi.org/10.1111/j.1365-3180.1995.tb01629.x, (1995).

26. Farooq, M., Basra, S. M. A., Afzal, I., \& Khaliq, A. Optimization of hydropriming techniques for rice seed invigoration. Seed Sci. Technol. 34(2),507-512, DOI: https://doi.org/10.15258/sst.2006.34.2.25, (2006).

27. Finch-Savage, W. E. \& Bassel, G. W. Seed vigour and crop establishment: extending performance beyond adaptation. J. Exp. Bot. 67,567-591, DOI: https://doi.org/10.1093/jxb/erv490, (2016).

28. He, M., Zhu, C., Dong, K., Zhang, T., Cheng, Z., Li, J. \& Yan, Y. Comparative proteome analysis of embryo and endosperm reveals central differential expression proteins involved in wheat seed germination. BMC Plant Biol. 15,1-17, DOI: https://doi.org/10.1186/s12870-015-0471-z, (2015).

29. Wojtyla, Ł., Lechowska, K., Kubala, S. \& Garnczarska, M. Molecular processes induced in primed seeds - increasing the potential to stabilize crop yields under drought conditions. J. Plant Physiol. 203,116-126, DOI: https://doi.org/10.1016/j.jplph.2016.04.008, (2016).

30. Ma, Z., Bykova, N. V. \& Igamberdiev, A. U. Cell signaling mechanisms and metabolic regulation of germination and dormancy in barley seeds. Crop J. 5,459-477, DOI: https://doi.org/10.1016/j.cj.2017.08.007, (2017).

31. Sharma, S. N. \& Maheshwari, A. Expression patterns of DNA repair genes associated with priming small and large chickpea (Cicer arietinum) seeds. Seed Sci. Technol. 43,250-261, DOI: https://doi.org/10.15258/sst.2015.43.2.11, (2015).

32. Forti, C., Ottobrino, V., Bassolino, L., Toppino, L., Rotino, G. L., Pagano, A., Macovei, A. \& Balestrazzi, A. Molecular dynamics of pre-germinative metabolism in primed eggplant (Solanum melongena L.) seeds. Hortic. Res. 7,87, DOI: https://doi.org/10.1038/s41438-020-0310-8, (2020).

33. ISTA. International Rules for Seed Testing 2015. International Seed Testing Association, Bassersdorf, Switzerland, (2015).

34. Maguire, J. D. Speed of germination-aid selection and evaluation for seedling emergence and vigor. Crop Sci. 2,176-177, (1962).

35. Abdul-Baki, A. A. \& Anderson, J. D. Vigour determination in soybean seed by multiple criteria. Crop Sci. 13,630-633, (1973).

\section{Author contributions statement}

V.S.M. and H.T. conceptualized the experiment. H.T. and S. Sharma conducted the experiment. M.K., J.Y. and S. Sangwan analyzed the results. H.T. and S. Sharma wrote the original draft of manuscript. A.B. prepared the figures. V.S.M., V.S., S.Y., J.S. and K.S. edited and reviewed the manuscript and also provided necessary advice during the course of experimentation. All the authors have reviewed the manuscript and approved the final version. 


\section{Additional information}

The authors have obtained the necessary permissions to collect the seeds and use them for research purposes.

It is confirmed that all methods were carried out in accordance with relevant guidelines and regulations.

Competing interests

The authors declare no competing interests.

Table 2. Main effects of genotype, water volume and soaking duration on standard germination (\%) and germination speed of wheat seed

\begin{tabular}{|c|c|c|c|c|c|}
\hline \multirow{2}{*}{ Main effects } & \multirow{2}{*}{ Levels } & \multicolumn{2}{|c|}{ Standard germination $(\%)^{\#}$} & \multicolumn{2}{|c|}{ Germination speed } \\
\hline & & $20^{\circ} \mathrm{C}$ & $25^{\circ} \mathrm{C}$ & $20^{\circ} \mathrm{C}$ & $25^{\circ} \mathrm{C}$ \\
\hline \multirow[t]{3}{*}{ Genotype, gp } & WH 1105 & $94.69(77.60) \mathrm{a}$ & $94.22(76.88) \mathrm{a}$ & $60.48 b$ & $66.27 \mathrm{~b}$ \\
\hline & WH 1124 & 93.68 (76.39)a & $93.72(76.46) \mathrm{a}$ & $62.12 \mathrm{a}$ & $67.73 a$ \\
\hline & KRL 213 & $92.35(74.95) \mathrm{b}$ & $91.79(74.38) \mathrm{b}$ & $58.64 \mathrm{c}$ & $64.25 \mathrm{c}$ \\
\hline \multirow[t]{3}{*}{ Water volume, wv } & Half & $93.71(76.58)$ & $93.58(76.36)$ & $59.14 \mathrm{c}$ & $65.28 \mathrm{~b}$ \\
\hline & Equal & $93.54(76.28)$ & $92.99(75.64)$ & $61.72 \mathrm{a}$ & $67.19 \mathrm{a}$ \\
\hline & Double & $93.47(76.08)$ & $93.17(75.72)$ & $60.38 b$ & $65.78 \mathrm{~b}$ \\
\hline \multirow[t]{8}{*}{ Soaking duration, sd } & $0 \mathrm{~h}$ (Control) & $93.33(75.04) \mathrm{c}$ & $92.44(74.19) \mathrm{c}$ & $40.67 \mathrm{~g}$ & $47.41 \mathrm{~g}$ \\
\hline & $1 \mathrm{~h}$ & $94.48(76.77) \mathrm{bc}$ & $94.11(76.29) b c$ & $51.52 \mathrm{f}$ & $56.74 \mathrm{f}$ \\
\hline & $2 \mathrm{~h}$ & $95.41(77.94) \mathrm{b}$ & $95.11(77.60) \mathrm{b}$ & $58.57 \mathrm{~d}$ & $63.69 d$ \\
\hline & $4 \mathrm{~h}$ & $96.00(78.74) \mathrm{ab}$ & $95.63(78.28) \mathrm{b}$ & $66.52 \mathrm{c}$ & $71.69 c$ \\
\hline & $8 \mathrm{~h}$ & $97.15(80.62) \mathrm{a}$ & $97.15(80.49) \mathrm{ab}$ & $71.67 \mathrm{~b}$ & $77.43 b$ \\
\hline & $12 \mathrm{~h}$ & $97.52(81.22) \mathrm{a}$ & $97.41(81.04) \mathrm{a}$ & $74.85 \mathrm{a}$ & $80.39 a$ \\
\hline & $16 \mathrm{~h}$ & $92.70(74.85) \mathrm{c}$ & $92.70(74.88) \mathrm{c}$ & $65.28 \mathrm{c}$ & $71.87 \mathrm{c}$ \\
\hline & $20 \mathrm{~h}$ & $82.00(64.92) \mathrm{d}$ & $81.41(64.49) \mathrm{d}$ & $54.22 \mathrm{e}$ & $59.45 \mathrm{e}$ \\
\hline $\mathrm{LSD}_{\mathrm{gp}}$ & & (1.01) & $(0.93)$ & 0.94 & 0.98 \\
\hline $\mathrm{LSD}_{\mathrm{wv}}$ & & $\mathrm{NS}$ & NS & 0.94 & 0.98 \\
\hline $\mathrm{LSD}_{\mathrm{sd}}$ & & 1.65 & 1.53 & 1.54 & 1.60 \\
\hline d.f. & & 144 & 144 & 144 & 144 \\
\hline
\end{tabular}

Values with different letters within a column (for each main effect) differ significantly from each other $(\mathrm{P}<0.05)$.

LSD, least significant differences between the treatments; d.f., degrees of freedom for the residual term.

\#Value in the parentheses are arc-sine transformed means of the original. 
Table 3. Main effects of genotype, water volume and soaking duration of hydropriming on seedling growth characteristics in wheat

\begin{tabular}{|c|c|c|c|c|c|c|c|}
\hline \multirow{2}{*}{ Main effects } & \multirow{2}{*}{ Levels } & \multicolumn{2}{|c|}{ Shoot length (cm) } & \multicolumn{2}{|c|}{ Root length $(\mathrm{cm})$} & \multicolumn{2}{|c|}{ Seedling length (cm) } \\
\hline & & $20^{\circ} \mathrm{C}$ & $25^{\circ} \mathrm{C}$ & $20^{\circ} \mathrm{C}$ & $25^{\circ} \mathrm{C}$ & $20^{\circ} \mathrm{C}$ & $25^{\circ} \mathrm{C}$ \\
\hline \multirow[t]{3}{*}{ Genotype, gp } & WH 1105 & $8.89 a$ & $10.83 b$ & $18.42 b$ & $20.37 \mathrm{c}$ & $27.31 \mathrm{~b}$ & $31.20 \mathrm{~b}$ \\
\hline & WH 1124 & $8.10 \mathrm{~b}$ & $10.48 \mathrm{c}$ & $19.97 \mathrm{a}$ & $22.14 \mathrm{a}$ & $27.99 a$ & $32.62 \mathrm{a}$ \\
\hline & KRL 213 & $8.84 \mathrm{a}$ & $11.39 \mathrm{a}$ & $17.76 \mathrm{c}$ & $21.02 \mathrm{~b}$ & $26.60 \mathrm{c}$ & $32.41 \mathrm{a}$ \\
\hline \multirow[t]{3}{*}{ Water volume, wv } & Half & $8.65 \mathrm{a}$ & $11.00 \mathrm{a}$ & 18.86 & $21.32 \mathrm{a}$ & 27.49 & $32.32 \mathrm{a}$ \\
\hline & Equal & $8.66 \mathrm{a}$ & $10.92 \mathrm{a}$ & 18.64 & $21.26 \mathrm{a}$ & 27.26 & $32.17 \mathrm{a}$ \\
\hline & Double & $8.52 \mathrm{~b}$ & $10.78 \mathrm{~b}$ & 18.66 & $20.96 \mathrm{~b}$ & 27.15 & $31.74 \mathrm{~b}$ \\
\hline \multirow[t]{8}{*}{ Soaking duration, sd } & $0 \mathrm{~h}$ (Control) & $7.50 \mathrm{e}$ & $9.86 f$ & $17.29 \mathrm{e}$ & $20.53 \mathrm{~d}$ & $24.57 \mathrm{f}$ & $30.39 \mathrm{e}$ \\
\hline & $1 \mathrm{~h}$ & $8.27 \mathrm{~d}$ & $10.80 \mathrm{~d}$ & $18.06 \mathrm{~cd}$ & $21.03 c$ & $26.33 \mathrm{e}$ & $31.84 d$ \\
\hline & $2 \mathrm{~h}$ & $8.45 \mathrm{~d}$ & $11.03 \mathrm{c}$ & $18.43 \mathrm{c}$ & $21.24 \mathrm{bc}$ & $26.88 \mathrm{~d}$ & $32.27 \mathrm{~cd}$ \\
\hline & $4 \mathrm{~h}$ & $8.87 \mathrm{c}$ & $10.93 \mathrm{~cd}$ & $19.14 b$ & $21.51 \mathrm{~b}$ & $28.00 \mathrm{c}$ & $32.44 \mathrm{c}$ \\
\hline & $8 \mathrm{~h}$ & $9.07 \mathrm{~b}$ & $11.51 \mathrm{~b}$ & $19.82 \mathrm{a}$ & $21.86 \mathrm{ab}$ & $28.89 \mathrm{~b}$ & $33.37 \mathrm{~b}$ \\
\hline & $12 \mathrm{~h}$ & $9.37 \mathrm{a}$ & $11.78 \mathrm{a}$ & $20.11 \mathrm{a}$ & $22.09 \mathrm{a}$ & $29.48 \mathrm{a}$ & $33.88 \mathrm{a}$ \\
\hline & $16 \mathrm{~h}$ & $9.02 b c$ & $11.00 \mathrm{~cd}$ & $18.95 \mathrm{~b}$ & $21.07 \mathrm{c}$ & $27.97 \mathrm{c}$ & $32.06 \mathrm{~cd}$ \\
\hline & $20 \mathrm{~h}$ & $8.33 \mathrm{~d}$ & $10.28 \mathrm{e}$ & $17.96 \mathrm{~d}$ & $20.07 \mathrm{e}$ & $26.29 \mathrm{e}$ & $30.35 \mathrm{e}$ \\
\hline $\mathrm{LSD}_{\mathrm{gp}}$ & & 0.12 & 0.13 & 0.23 & 0.24 & 0.28 & 0.29 \\
\hline $\mathrm{LSD}_{\mathrm{wv}}$ & & 0.12 & 0.13 & NS & 0.24 & NS & 0.29 \\
\hline $\mathrm{LSD}_{\mathrm{sd}}$ & & 0.19 & 0.22 & 0.38 & 0.39 & 0.46 & 0.47 \\
\hline d.f. & & 144 & 144 & 144 & 144 & 144 & 144 \\
\hline
\end{tabular}

Values with different letters within a column (for each main effect) differ significantly from each other $(\mathrm{P}<0.05)$.

LSD, least significant differences between the treatments; d.f., degrees of freedom for the residual term. 
Table 4. Main effects of genotype, water volume and soaking duration of hydropriming on seedling biomass in wheat

\begin{tabular}{|c|c|c|c|c|c|}
\hline \multirow{2}{*}{ Main effects } & \multirow{2}{*}{ Levels } & \multicolumn{2}{|c|}{ Seedling fresh weight (mg) } & \multicolumn{2}{|c|}{ Seedling dry weight (mg) } \\
\hline & & $20^{\circ} \mathrm{C}$ & $25^{\circ} \mathrm{C}$ & $20^{\circ} \mathrm{C}$ & $25^{\circ} \mathrm{C}$ \\
\hline \multirow[t]{3}{*}{ Genotype, gp } & WH 1105 & $130.46 b$ & $136.87 \mathrm{c}$ & $13.01 \mathrm{~b}$ & $14.18 \mathrm{c}$ \\
\hline & WH 1124 & $177.04 \mathrm{a}$ & $193.02 \mathrm{a}$ & $14.84 \mathrm{a}$ & $17.45 \mathrm{a}$ \\
\hline & KRL 213 & $126.51 \mathrm{c}$ & $153.70 \mathrm{~b}$ & $12.66 \mathrm{c}$ & $15.38 \mathrm{~b}$ \\
\hline \multirow[t]{3}{*}{ Water volume, wv } & Half & 143.81 & 162.84 & 13.50 & 15.57 \\
\hline & Equal & 146.60 & 161.95 & 13.55 & 15.78 \\
\hline & Double & 143.60 & 158.80 & 13.46 & 15.65 \\
\hline \multirow[t]{8}{*}{ Soaking duration, sd } & $0 \mathrm{~h}$ (Control) & $120.53 d$ & $140.46 \mathrm{e}$ & $12.70 \mathrm{~d}$ & $15.04 d$ \\
\hline & $1 \mathrm{~h}$ & $133.36 \mathrm{c}$ & $149.86 \mathrm{~d}$ & $13.23 \mathrm{c}$ & $15.50 \mathrm{c}$ \\
\hline & $2 \mathrm{~h}$ & $137.93 \mathrm{c}$ & $158.99 \mathrm{c}$ & $13.60 \mathrm{~b}$ & $15.70 \mathrm{bc}$ \\
\hline & $4 \mathrm{~h}$ & $148.90 \mathrm{~b}$ & $166.54 b$ & $13.80 \mathrm{~b}$ & $15.98 \mathrm{~b}$ \\
\hline & $8 \mathrm{~h}$ & $161.56 \mathrm{a}$ & $178.82 \mathrm{a}$ & $14.19 \mathrm{a}$ & $16.60 \mathrm{a}$ \\
\hline & $12 \mathrm{~h}$ & $166.41 \mathrm{a}$ & $181.19 \mathrm{a}$ & $14.39 \mathrm{a}$ & $16.54 \mathrm{a}$ \\
\hline & $16 \mathrm{~h}$ & $151.93 b$ & $164.10 \mathrm{bc}$ & $13.54 \mathrm{bc}$ & $15.38 \mathrm{~cd}$ \\
\hline & $20 \mathrm{~h}$ & $136.75 \mathrm{c}$ & $149.63 \mathrm{~d}$ & $12.56 \mathrm{~d}$ & $14.60 \mathrm{e}$ \\
\hline $\mathrm{LSD}_{\mathrm{gp}}$ & & 3.68 & 3.47 & 0.19 & 0.23 \\
\hline $\mathrm{LSD}_{\mathrm{wv}}$ & & NS & NS & NS & NS \\
\hline $\mathrm{LSD}_{\mathrm{sd}}$ & & 6.01 & 5.67 & 0.31 & 0.37 \\
\hline d.f. & & 144 & 144 & 144 & 144 \\
\hline
\end{tabular}

Values with different letters within a column (for each main effect) differ significantly from each other $(\mathrm{P}<0.05)$.

LSD, least significant differences between the treatments; d.f., degrees of freedom for the residual term. 
Table 5. Main effects of genotype, water volume and soaking duration of hydropriming on seedling vigour indices in wheat

\begin{tabular}{|c|c|c|c|c|c|}
\hline \multirow{2}{*}{ Main effects } & \multirow{2}{*}{ Levels } & \multicolumn{2}{|c|}{ Seedling vigour index-I } & \multicolumn{2}{|c|}{ Seedling vigour index-I } \\
\hline & & $20^{\circ} \mathrm{C}$ & $25^{\circ} \mathrm{C}$ & $20^{\circ} \mathrm{C}$ & $25^{\circ} \mathrm{C}$ \\
\hline \multirow[t]{3}{*}{ Genotype, gp } & WH 1105 & $2526 \mathrm{~b}$ & $2945 b$ & $1234 b$ & $1338 \mathrm{c}$ \\
\hline & WH 1124 & $2627 \mathrm{a}$ & $3061 \mathrm{a}$ & $1392 \mathrm{a}$ & $1636 \mathrm{a}$ \\
\hline & KRL 213 & $2521 b$ & $2979 b$ & $1171 \mathrm{c}$ & $1414 b$ \\
\hline \multirow[t]{3}{*}{ Water volume, wv } & Half & 2578 & $3027 \mathrm{a}$ & 1266 & 1459 \\
\hline & Equal & 2553 & $2995 \mathrm{ab}$ & 1270 & 1470 \\
\hline & Double & 2543 & $2963 b$ & 1262 & 1460 \\
\hline \multirow[t]{8}{*}{ Soaking duration, sd } & $0 \mathrm{~h}$ (Control) & $2293 f$ & $2810 \mathrm{~d}$ & $1185 \mathrm{~d}$ & 1391d \\
\hline & $1 \mathrm{~h}$ & $2488 \mathrm{e}$ & $2995 c$ & $1250 \mathrm{c}$ & $1458 \mathrm{c}$ \\
\hline & $2 \mathrm{~h}$ & $2564 d$ & $3070 b$ & $1298 b$ & $1493 \mathrm{bc}$ \\
\hline & $4 \mathrm{~h}$ & $2688 \mathrm{c}$ & $3102 b$ & $1325 b$ & $1528 b$ \\
\hline & $8 \mathrm{~h}$ & $2806 b$ & $3242 a$ & $1378 \mathrm{a}$ & $1613 a$ \\
\hline & $12 \mathrm{~h}$ & $2874 a$ & $3299 a$ & $1403 a$ & $1610 \mathrm{a}$ \\
\hline & $16 \mathrm{~h}$ & $2596 \mathrm{~d}$ & $2973 c$ & $1257 \mathrm{c}$ & $1426 \mathrm{~cd}$ \\
\hline & $20 \mathrm{~h}$ & $2155 \mathrm{~g}$ & $2468 \mathrm{e}$ & $1029 \mathrm{e}$ & $1186 \mathrm{e}$ \\
\hline $\mathrm{LSD}_{\mathrm{gp}}$ & & 32.94 & 39.51 & 21.36 & 23.10 \\
\hline $\mathrm{LSD}_{\mathrm{wv}}$ & & NS & 39.51 & NS & NS \\
\hline $\mathrm{LSD}_{\mathrm{sd}}$ & & 53.80 & 64.51 & 34.89 & 37.72 \\
\hline d.f. & & 144 & 144 & 144 & 144 \\
\hline
\end{tabular}

Values with different letters within a column (for each main effect) differ significantly from each other $(\mathrm{P}<0.05)$.

LSD, least significant differences between the treatments; d.f., degrees of freedom for the residual term. 
Table 6. Assessment of different treatment combinations on the basis of Hydropriming Optimization Score (HPOS) in primed wheat seed

\begin{tabular}{|c|c|c|c|c|c|c|}
\hline $\begin{array}{l}\text { Sr. } \\
\text { No. }\end{array}$ & Priming treatments & $\begin{array}{c}\text { Water } \\
\text { Exposure } \\
\text { Index } \\
(\mathrm{WEI})^{*}\end{array}$ & $\begin{array}{l}\text { Standard } \\
\text { germination } \\
(\%)(\mathrm{SG})\end{array}$ & $\begin{array}{c}\text { Germination } \\
\text { speed (GS) }\end{array}$ & HPOS & Ranking \\
\hline 1. & $\mathrm{HV}+1 \mathrm{~h}$ & 42.43 & 94.00 & 50.97 & 66.10 & 20 \\
\hline 2. & $\mathrm{HV}+2 \mathrm{~h}$ & 84.85 & 95.00 & 57.12 & 71.34 & 15 \\
\hline 3. & $\mathrm{HV}+4 \mathrm{~h}$ & 169.71 & 95.62 & 63.70 & 76.46 & 11 \\
\hline 4. & $\mathrm{HV}+8 \mathrm{~h}$ & 339.41 & 96.89 & 69.95 & 81.24 & 9 \\
\hline 5. & $\mathrm{HV}+12 \mathrm{~h}$ & 509.12 & 98.33 & 75.87 & 85.65 & 3 \\
\hline 6. & $\mathrm{HV}+16 \mathrm{~h}$ & 678.82 & 95.00 & 75.14 & 83.91 & 6 \\
\hline 7. & $\mathrm{HV}+20 \mathrm{~h}$ & 848.53 & 81.45 & 60.89 & 69.68 & 17 \\
\hline 8. & $\mathrm{EV}+1 \mathrm{~h}$ & 60.00 & 94.39 & 55.06 & 69.55 & 18 \\
\hline 9. & $\mathrm{EV}+2 \mathrm{~h}$ & 120.00 & 95.45 & 62.59 & 75.60 & 13 \\
\hline 10. & $\mathrm{EV}+4 \mathrm{~h}$ & 240.00 & 95.89 & 71.03 & 81.61 & 8 \\
\hline 11. & $\mathrm{EV}+8 \mathrm{~h}$ & 480.00 & 97.11 & 75.17 & 84.74 & 5 \\
\hline 12. & $\mathrm{EV}+12 \mathrm{~h}$ & 720.00 & 97.50 & 81.06 & 88.52 & 1 \\
\hline 13. & $\mathrm{EV}+16 \mathrm{~h}$ & 960.00 & 92.78 & 68.76 & 78.98 & 10 \\
\hline 14. & $\mathrm{EV}+20 \mathrm{~h}$ & 1200.00 & 80.11 & 57.92 & 67.23 & 19 \\
\hline 15. & $\mathrm{DV}+1 \mathrm{~h}$ & 84.85 & 94.50 & 56.36 & 70.61 & 16 \\
\hline 16. & $\mathrm{DV}+2 \mathrm{~h}$ & 169.71 & 95.33 & 63.70 & 76.37 & 12 \\
\hline 17. & $\mathrm{DV}+4 \mathrm{~h}$ & 339.41 & 95.95 & 72.59 & 82.65 & 7 \\
\hline 18. & $\mathrm{DV}+8 \mathrm{~h}$ & 678.82 & 97.44 & 78.53 & 86.97 & 2 \\
\hline 19. & $\mathrm{DV}+12 \mathrm{~h}$ & 1018.23 & 96.56 & 75.95 & 85.02 & 4 \\
\hline 20. & $\mathrm{DV}+16 \mathrm{~h}$ & 1357.65 & 90.33 & 61.84 & 73.41 & 14 \\
\hline 21. & $\mathrm{DV}+20 \mathrm{~h}$ & 1697.06 & 83.56 & 51.70 & 63.87 & 21 \\
\hline 22. & Control (Unprimed) & - & 92.89 & 44.06 & 59.77 & 22 \\
\hline
\end{tabular}

${ }^{\#}$ Soaking in HV- Half volume, EV- Equal volume, DV- Double volume (w/v) with respect to weight of seed + Soaking duration in hours. HPOS $=(2 \times \mathrm{SG} \times \mathrm{GS}) / \mathrm{SG}+\mathrm{GS}$.

*WEI is calculated by following formula: $W E I=\sqrt{w v} \times s d$, where $\mathrm{wv}=$ water volume and sd= soaking duration in minutes 
Table 7. Correlation of Water Exposure Index and moisture content with germination and seedling vigour parameters

\begin{tabular}{|c|c|c|c|c|c|c|}
\hline & WEI & Mc & SG & GS & VI-I & VI-II \\
\hline WEI & 1.000 & & & & & \\
\hline Mc & $0.892^{* * *}$ & 1.000 & & & & \\
\hline SG & $-0.600^{* *}$ & $-0.317^{\mathrm{NS}}$ & 1.000 & & & \\
\hline GS & $0.053^{\mathrm{NS}}$ & $0.441^{*}$ & $0.571^{* * *}$ & 1.000 & & \\
\hline VI-I & $-0.465^{*}$ & $-0.120^{\mathrm{NS}}$ & $0.945^{* *}$ & $0.777^{* *}$ & 1.000 & \\
\hline VI-II & $-0.519^{*}$ & $-0.156^{\mathrm{NS}}$ & $0.950^{* *}$ & $0.748^{* *}$ & $0.984^{* *}$ & 1.000 \\
\hline
\end{tabular}

**Significant at 1\%, *Significant at 5\%, NS: Non-significant, WEI: Water Exposure Index, Mc: Moisture content, SG: Standard germination, GS: Germination speed, VI-I: Seedling vigour index-I, VI-II: Seedling vigour index-II

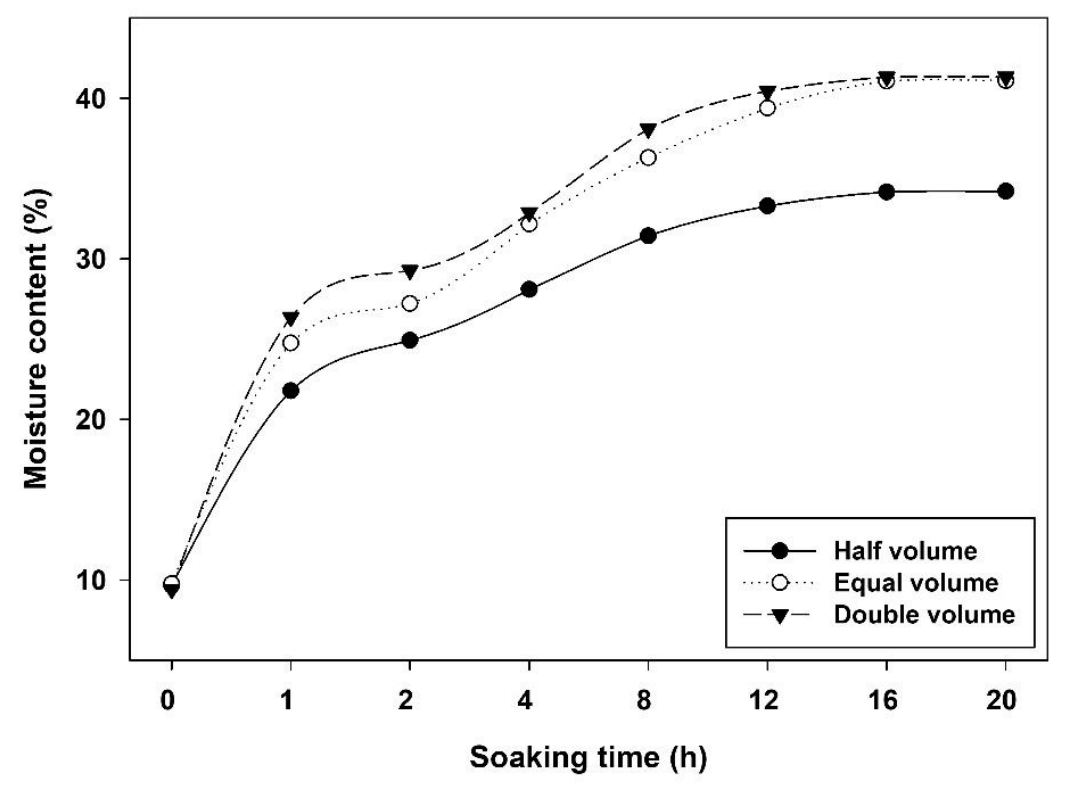

Fig. 1 

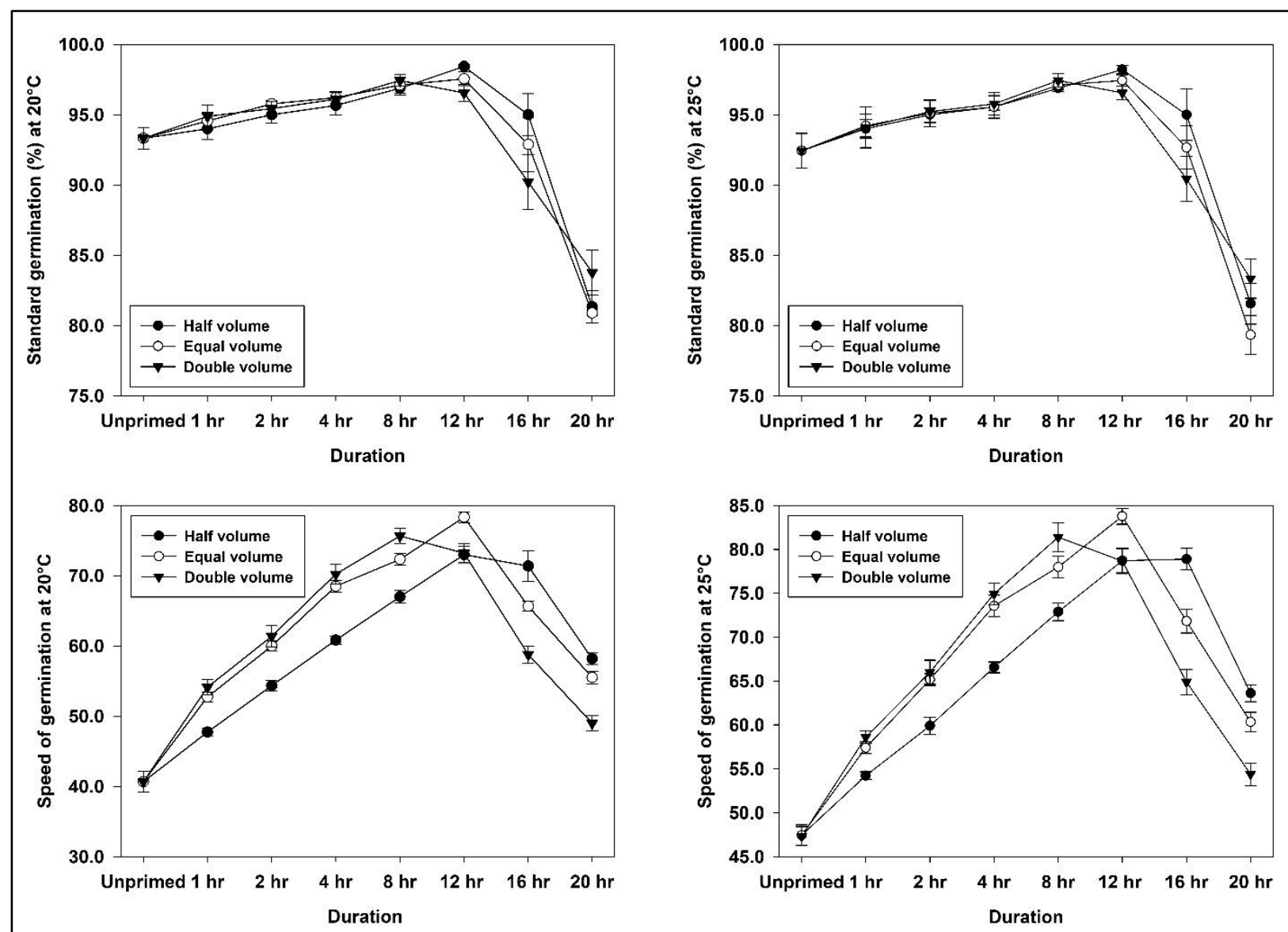

Fig. 2 

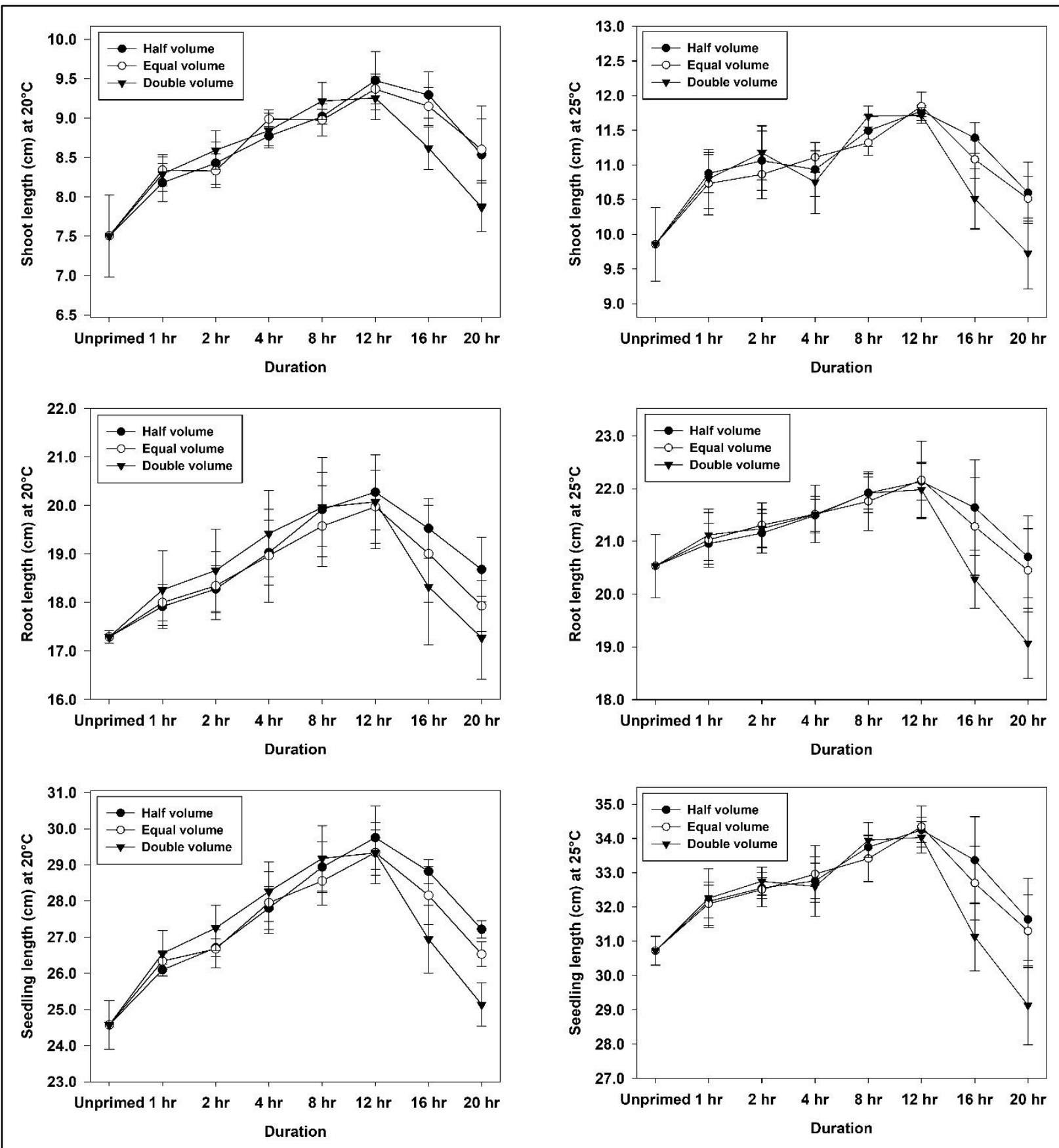

Fig. 3 

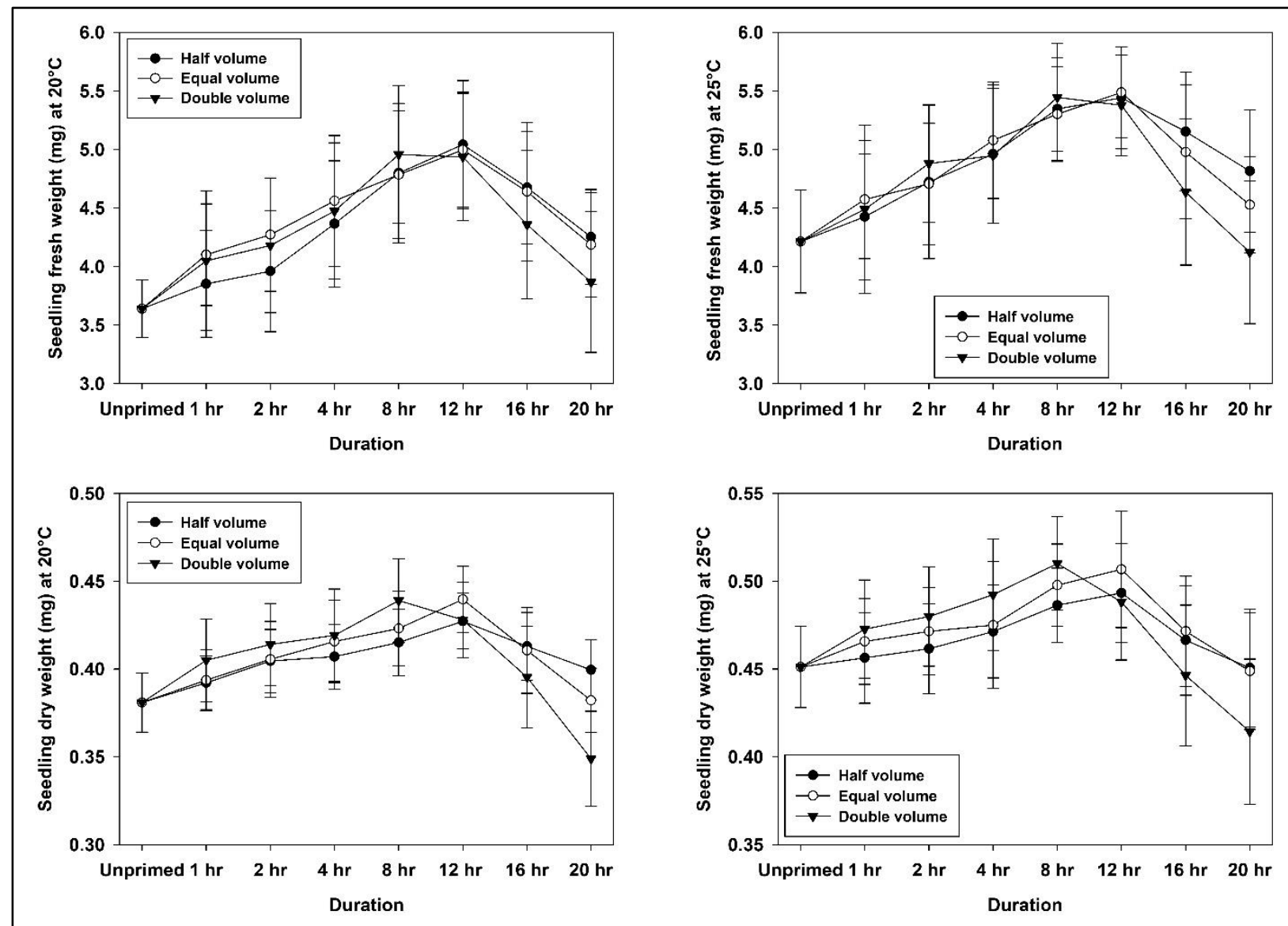

Fig. 4 

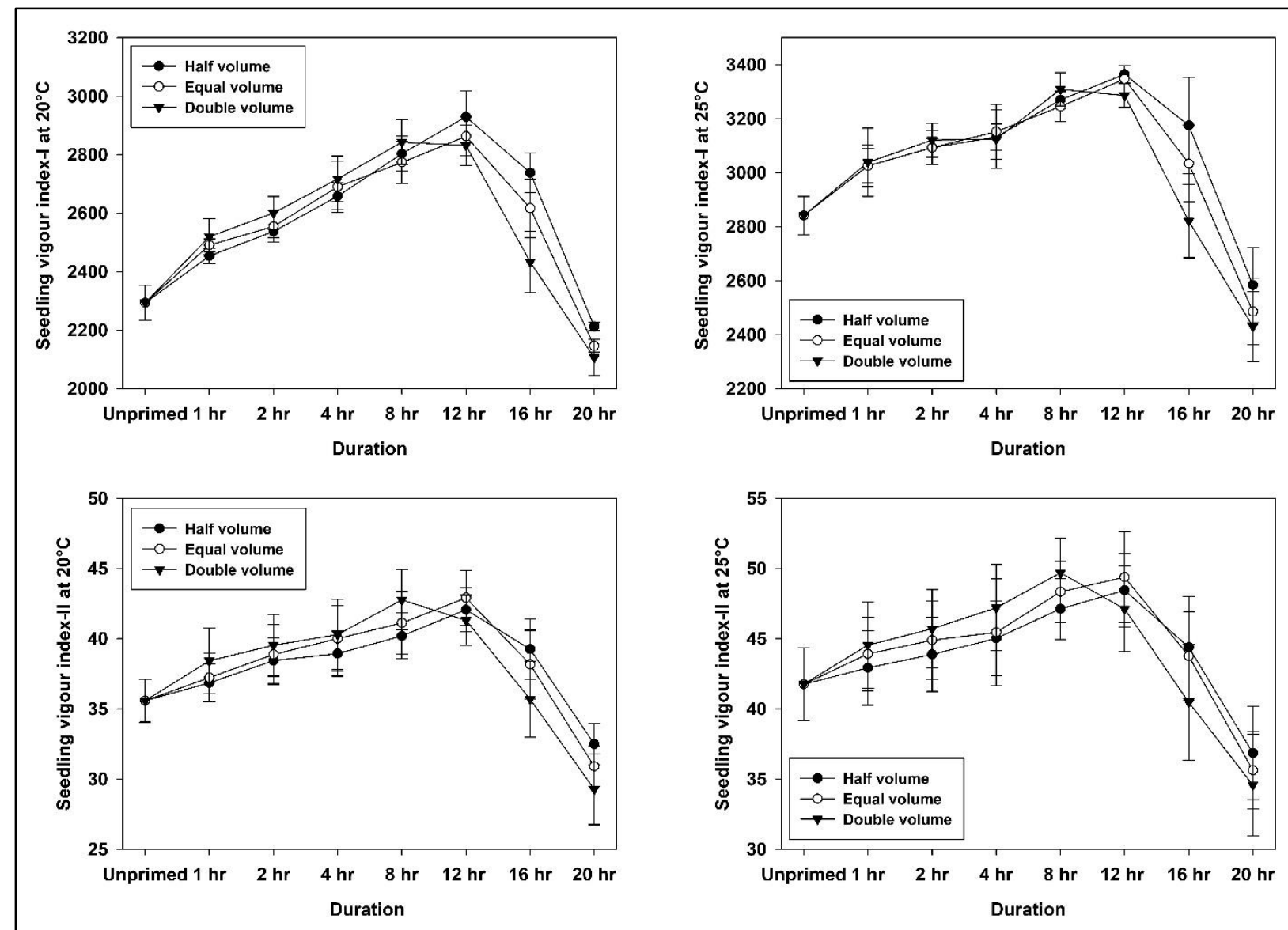

\section{Fig. 5}

\section{Figure legends:}

Fig. 1. Seed moisture content as influenced by soaking time and water volume during hydropriming of wheat

Fig. 2. Interactive effects of water volume and soaking duration of hydropriming on germination characteristics of wheat seed

Fig. 3. Interactive effects of water volume and soaking duration of hydropriming on seedling growth characteristics in wheat

Fig. 4. Interactive effects of water volume and soaking duration of hydropriming on seedling biomass in wheat

Fig. 5. Interactive effects of water volume and soaking duration of hydropriming on seedling vigour indices in wheat 